\title{
Research on Innovation of Bilingual Teaching Mode for Postgraduates in Local Colleges
}

\author{
Lijing $\mathrm{Wu}$ \\ Department of Law \\ College of Humanities and Law \\ North China University of Technology \\ Beijing, China 100144
}

\begin{abstract}
The importance of bilingual education has been widely recognized. However, the bottleneck of the development of bilingual teaching in local colleges is the shortage of competent teachers. To solve this problem, the limitation of classroom teaching shall be broken through and modules of professional courses, language courses, academic practice and community activities may be linked up to establish a multidimensional bilingual teaching mode.
\end{abstract}

Keywords—bilingual teaching; local colleges; teaching mode

\section{INTRODUCTION}

Bilingual teaching in universities means using non-native language in universities to teach all or part of the non language disciplines, referring to the system using English to teach. 1 With the increase of external exchange in China, especially the implementation of the Belt and Road strategy, compound talents with solid specialized knowledge and fluent in speaking foreign languages are in urgent need in our country. Many universities have provided the bilingual courses, especially for postgraduates, in order to meet the demands for talents in the society. However, with many restrictions, the bilingual teaching in universities does not reach the anticipated effects. Some special difficulties are faced by local colleges in the implementation of bilingual teaching. Next, the author will analyze and discuss the problem.

\section{INVESTIGATION ON THE CURRENT SITUATION OF BILINGUAL TEACHING FOR POSTGRADUATES IN LOCAL COLLEGES OF BEIJING}

In order to know about students' opinions on the bilingual course and the expectation for the teaching effect, the author has carried out the questionnaire survey on the bilingual teaching for postgraduates of the international law major in the North China University of Technology. The opinions and requirements of postgraduates on the bilingual teaching at present can be known according to the analysis on the questionnaire collected.

\section{A. Understanding of the Bilingual Course}

$80 \%$ of students think it is "very necessary" to open the bilingual courses and 20\% think "necessary". For the main

This paper is the phased research result of the topic, receiving the funding of key topic "Application of Bilingual Teaching in Courses Using the Comparative Method" of the educational reform in the North China University of Technology. purpose of choosing the bilingual courses, the popular reasons in the questionnaire include: Improve the level in reading the professional literature in foreign language, improve the listening and speaking level of foreign language and obtain more updated specialized knowledge, etc.

In regard to the bilingual specialty course, $50 \%$ of students think the professional contents are more important. 30\% think the thought of Britain, America and France is more important. Only $20 \%$ think the language is more important. As for the biggest problem in learning the bilingual courses, $60 \%$ of students think the professional contents are difficult, and $40 \%$ think the language foundation is poor "Fig. 1".

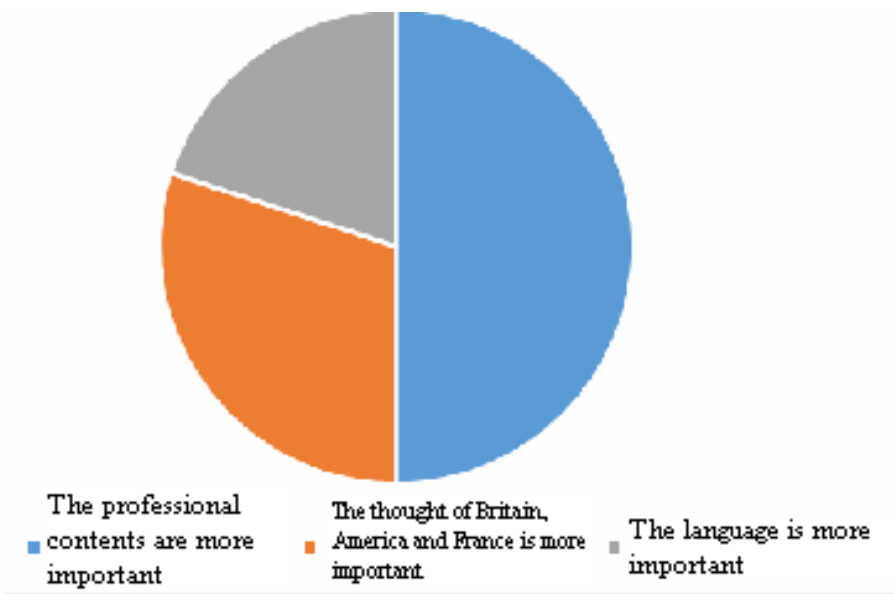

Fig. 1. Students' opinions on the importance of the learning objectives for specialized courses.

\section{B. The Teaching Mode of Bilingual Course}

For the teaching mode of bilingual course, $90 \%$ of students choose "the combination of teachers' instruction with students' discussion". $50 \%$ to $60 \%$ of students choose the teachers' instruction, and $40 \%$ to $50 \%$ choose the students' discussion. Besides, according to the results of questionnaire survey, students think it is necessary or very necessary to carry out the presentation in English, which can exercise and improve ability. $90 \%$ think the case discussion in English is necessary in class. 


\section{The Teaching Language of Bilingual Courses}

As for the application of English in teaching or organizing the discussion in class by teachers, $40 \%$ of students choose "mainly speak Chinese at the beginning of the semester, gradually increase the proportion of English and then to speak in English". 30\% hope "mainly speak in English and explain in Chinese when necessary". 20\% choose "the combination of Chinese and English". 10\% hope teachers can "speak in Chinese and then in English". No one choose the "teaching in English" or "mainly speak in Chinese" "Fig. 2".

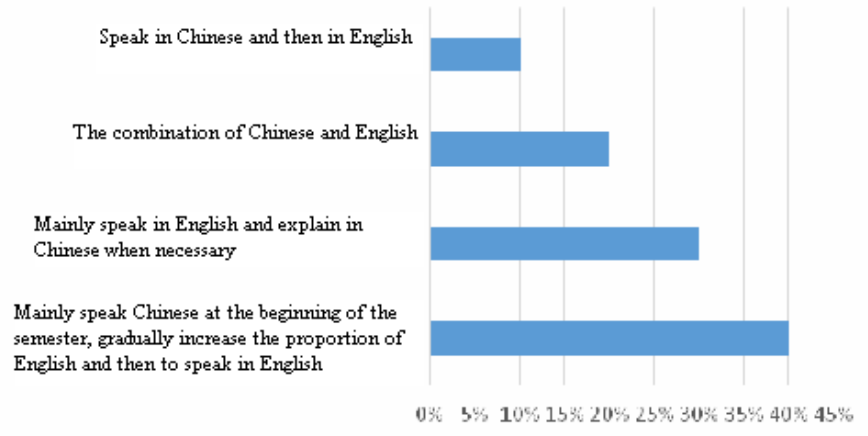

Fig. 2. Students' demands for the appliance of the two languages in class

As for the spoken language of teachers, $40 \%$ of students hope "they had better have pure British English pronunciation or American English pronunciation". 30\% think "they can have oral speech sounds but with clear pronunciation and slow down the speed". 30\% think "the pronunciation and speed are not important if it is understandable" "Fig. 3".

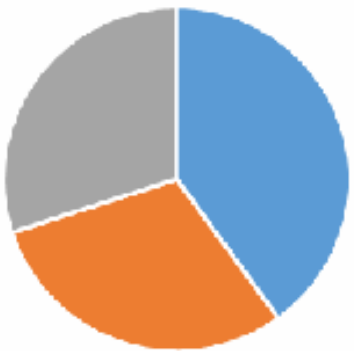

\footnotetext{
Had better hame pure Eritich Englich prommcintion or American Englich - promanciation

- Cmhare ond speech sounds but with clear prommiciation and slow down the speed

The proramcintion and speed are not importart if it is understandable
}

Fig. 3. Demands for teachers's spoken language

For the ability and quality of bilingual teachers, students first care for the reasonable design of teaching link (100\%), and then the moderate depth of teaching contents and proper arrangement $(90 \%)$ and strong oral expression ability $(80 \%)$, supplementary reading materials can be provided properly ( $80 \%)$, but don't regard the ability in courseware making as important (20\%) "Fig. 4".

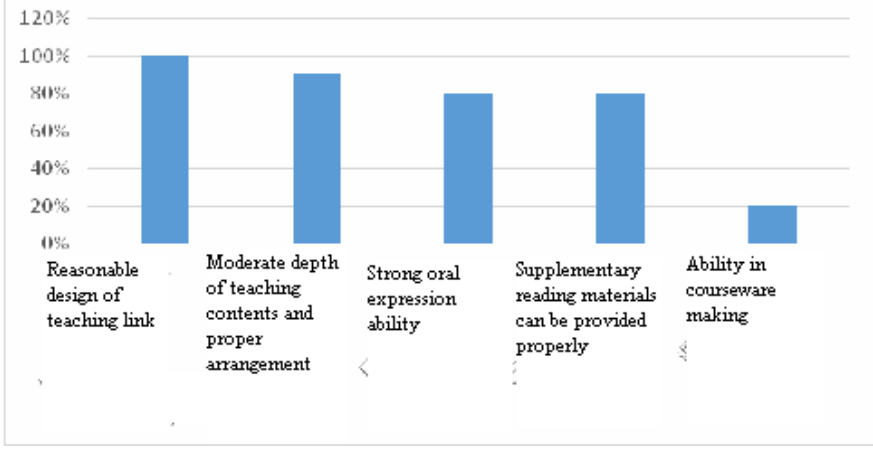

Fig. 4. Demands for bilingual teachers' ability

\section{Teaching Material Selection of the Bilingual Courses}

For the teaching materials of bilingual course, $40 \%$ of students prefer the foreign original teaching material. $30 \%$ prefer the teaching materials in Chinese and English. 30\% prefer the foreign original teaching material after being excerpted and edited "Fig. 5".

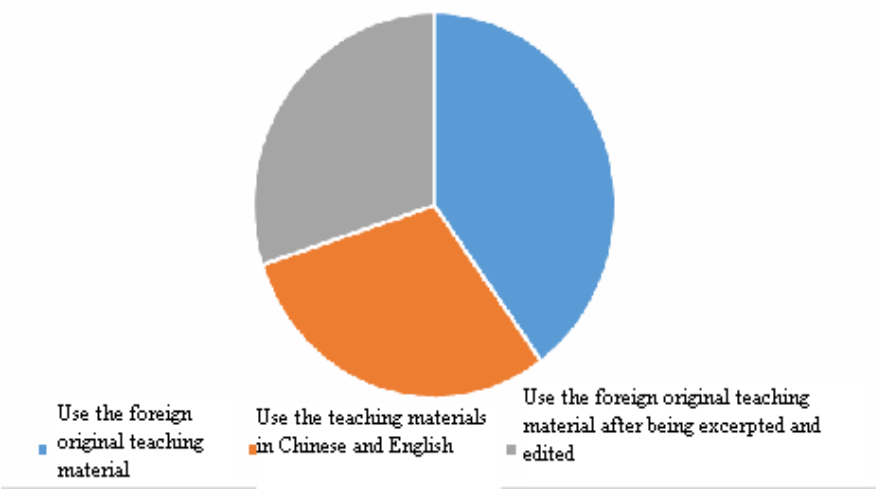

Fig. 5. Teaching material selection of the bilingual courses

Although the limitation of conditions exists and the questionnaire survey is only conducted among the postgraduates of the international law major in a university of Beijing, the above results more or less reflect the opinions of postgraduates on the bilingual courses: the necessity of opening the bilingual course in the postgraduate stage is accepted by them, while the purpose of choosing the bilingual courses is to improve the specialized knowledge and ability instead of the language level; for the selection of teaching mode, obviously, at present the students are not satisfied with the "duck-stuffing" type of teaching, they prefer the teachers' instruction involving the discussion and interaction in class, including students' presentation and case discussion; as for the teaching language, although slight difference exists in the selection of English, students prefer the combination of Chinese and English. As for the teachers' language competence, most students hope teachers can express clearly and then pursue the beautiful and authentic pronunciation and intonation; besides, most students prefer the original teaching materials or the original teaching materials after being edited, in order to learn the original professional English. 
Although teachers have teaching objectives and teaching arrangements of their own according to the syllabus, undoubtedly, the expectation and requirements of students for the course have provided important references for teachers to determine the teaching contents and choose the teaching methods. The result of the above questionnaire survey reflects students' requirements for teachers of bilingual courses and teachers' striving direction.

\section{ANALYSIS ON THE PREDICAMENT OF BILINGUAL} TEACHING FOR POSTGRADUATES IN LOCAL COLLEGES OF BEIJING

Although in recent years, universities have opened the bilingual courses successively, the actual teaching effects of bilingual teaching are not satisfying. The teaching methods and teaching mode have been one of the important contents of the research on teaching reform in recent years. The difficulties faced by the bilingual teaching and the existing problems have been analyzed and discussed in many articles. This paper only discuss the biggest difficulty-teachers in the provision of bilingual courses in local colleges.

The joint efforts and coordination of teachers and students are required in achieving the ideal teaching effects of bilingual courses. Teachers are distinctly important because their quality and ability determine the ultimate effect of courses. The author thinks the bilingual teaching means using two languages (mainly in Chinese and English) to teach the specialized knowledge. The learning of specialized knowledge is the primary teaching objective. The application of two languages is the tool to enlarge the professional vocabulary, improve the ability in reading foreign literatures and finally enhance the ability of thinking. The order of them cannot invert. Therefore, the specialty instead of the language competence is valued in appointing teachers. In view of this, the non-professional foreign language teachers and Chinese teachers of foreign language specialty are not the best candidates. Teachers of this specialty with English as the mother language are scarce and cannot understand Chinese. It has high demands for students in the English teaching environment. It is unrealistic for universities in Beijing, especially the non-key universities. The ideal choice is the teachers having studied or worked abroad for many years, familiar with the specialized knowledge and barrier free in expressing English. However, currently, competent teachers are rare and precious in local colleges of Beijing. Most teachers of bilingual courses in local colleges have got the doctoral degree yet don't study or work abroad for a long time. 2 They may be competent in reading the English literatures but difficult in expressing the professional contents correctly and fluently. To clearly state the professional contents, in classroom teaching, they mainly use Chinese, the proportion of which has exceeded $50 \%$. Therefore, both teachers and students depend on the Chinese consciously or unconsciously, getting away from the original intention in opening the bilingual course. The insufficient English input in the classroom teaching directly influences the formation of English language environment of students and the effective English output. The author thinks it has become the bottleneck to restrict the bilingual teaching development in local colleges of Beijing that it lacks of teachers, teachers of bilingual courses are incompetent in expressing in English fluently and the English input is inadequate in teaching.

Many educators and researchers also have realized the problem. The popular solution is to strengthen the teacher training, including the training at home and overseas training for a period of time. Although the training of bilingual teaching lasting for one to several weeks takes effect, it cannot get effect instantly; the language competence of teachers can be improved rapidly after they study abroad for some time, but the opportunity is rare. At present, it cannot be popularized in a large scale among bilingual teachers.

With respect to the predicament, the author thinks on one hand, teachers should vigorously strengthen the self-training and improvement and take full advantage of the English learning resources and software to improve their oral expression ability; on the other hand, students' effective English input can be increased through the expansion of thoughts and model innovation of bilingual teaching.

\section{MODEL INNOVATION OF BILINGUAL TEACHING FOR POSTGRADUATES IN LOCAL COLLEGES OF BEIJING}

Although in recent years, the reform and innovation of teaching mode have been the key and hot issue of researches on the teaching reform, and the new teaching idea and teaching technique also appear continuously, most teaching researches focus on the classroom and extend to the part before and after class at most. 3 The author suggests, the innovation of teaching model to make up for the deficiency of insufficient bilingual teachers in local colleges of Beijing, except for the student centered mode, strengthening the interaction between teachers and students and making the best of network resources and new educational technologies suggested by other scholars, 4 should consider breaking through the classroom teaching, connecting the bilingual teaching of specialized courses with the English teaching for postgraduates, the classroom teaching with academic practical activities, the course learning with club activities, to form an all-round multi-dimensional teaching mode and cover the shortage of English input in the bilingual class.

\section{A. The Connection of Bilingual Teaching of the Specialized Courses with the English Teaching for Postgraduates}

Except for the specialized courses, language courses like the graduate English and the professional English are also provided in the postgraduate stage, such as the law English provided in the law major in which the author engages. If teachers of the bilingual specialized course can cooperate with teachers of the graduate English and the professional English to research the teaching reform, they will supplement each other on the teaching contents, making up for the deficiency of English input of the specialized courses through the English input of language courses. Both sides will benefit through enriching the teaching of language courses with the contents of specialized courses. 


\section{B. The Connection of Classroom Teaching and Academic Practice}

In the postgraduate education, except for getting credits through taking the specialized courses listed in the training plan, postgraduates should also participate in some academic practical activities. For example: 1. The reading party. Teachers from different specialties organize the reading party and lead the postgraduates to read up the classic works including the original English works. Although it is not the contents taught in the bilingual courses, it can increase the English input of related professional knowledge. 2. The paper workshop. Taking the Department of Law in the College of Humanities and Law where the author is in as an example, some teachers organize the paper workshop, choose the topics for postgraduates and lead them to read the literatures and cases in Chinese and English, finally completing the paper of related topics. It also has the professional English input. 3. The case workshop. This is a case discussion group organized by the author, choosing the classic cases in English in the field of international law, WTO and ICSID, leading postgraduates to read English materials, including the legal documents submitted $\mathrm{b}$ the participants and the report of experts or the adjudication of the arbitrators. Some cases have direct relationship with the bilingual courses of international law, echoing with the teaching contents. 4. The professional English contest. Taking the law major as an example, teachers can organize students to participate in the professional competitions like the Willen C. Vis International Commercial Arbitration Moot, Philip C. Jessup International Law Moot Court Competition. It involves the reading and writing of English materials in the preparation. The learning effects will be improved through the competitions. 5. Academic lecture in English. Attending the academic lecture in English, postgraduates can increase the professional English input. The participation in the academic lecture in English can be regarded as one of the elements to assess the results of bilingual courses at ordinary times. The teaching of bilingual courses can connect with the academic lecture in English, in order to enrich students' English input through the application of open extracurricular academic resources.

\section{Connection of the Course Learning with the Club Activities}

At present, abundant club activities exist in universities, including the English Corner, English Association, English speech contest and English Drama Contest. Teachers of bilingual courses can encourage and organize the students in the bilingual class to participate in the above club or contests to increase the English input. The author opens the bilingual course of International Trade Law for postgraduates in the International Law Major. Students in this class have applied and established the TED NCUT in this school and will share through English lecture for the first time. The above activities can increase the interestingness and interaction of English learning and then promote the teaching of bilingual courses.

\section{CONCLUSION}

To sum up, the English input in the bilingual course can break through the classroom teaching, expanding to language courses, academic practical activities and club activities. The efforts and coordination of teachers contribute to the interaction and connection of classroom teaching, practical teaching and club activities, and the establishment of all-round multi-dimensional teaching mode. The effective input of English will be increased through various channels to create better English-speaking environment, cover the shortage of teachers for bilingual courses in local colleges and promote the realization of bilingual teaching objectives.

\section{REFERENCES}

[1] Luo Libin. Research Status of the Domestic Bilingual Teaching: Summary on the Literatures in the Recent Five Years, Education and Teaching Forum, 2013(11)

[2] According to the sample survey of bilingual teachers in ten universities, there are only $13.2 \%$ undertaking the task of bilingual teaching, having the experiences of overseas study, work or visit study. Kang Shumin, Cui Xinchun, Research on the Bilingual Teaching Practice in University under the Support of Information Technology, Computer-assisted Foreign Language Education, 2009(2). This is the survey data of national universities (including the national key universities). The proportion may be lower if sample survey is conducted in local colleges.

[3] Luo Libin. Research Status of the Domestic Bilingual Teaching: Summary on the Literatures in the Recent Five Years, Education and Teaching Forum, 2013(11)

[4] Zhang Zhiying. Problems of Bilingual Teaching in Universities and Countermeasures, Heilongjiang Education: Higher Education Research and Evaluation, 2012(3); Wei Yaping. Application of Embedded Concept of Bilingual Teaching in the Specialized Basic Course Teaching-Take the Course of Methods for Social Investigation as an Example, Journal of Xinjiang Normal University: Philosophy and Social Sciences Edition, 2011, 32(1) 